ISSN 1816-6075 (Print), 1818-0523 (Online)

Journal of System and Management Sciences

Vol. 9 (2019) No. 1, pp. 19-47

DOI:10.33168/JSMS.2019.0102

\title{
Information Sharing in Supply Chain Management: A Case Study Between the Cooperative Partners in Manufacturing Industry
}

\author{
Tasnia Hassan Nazifa ${ }^{1}$, K.K Ramachandran ${ }^{2}$ \\ ${ }^{1}$ UTM, Skudai, 81310, Johor Bahru, Malaysia \\ ${ }^{2}$ GRD Institute of Management and International Business, Coimbatore, Tamil Nadu, India \\ thnafisa@grad.stud.utm.my
}

\begin{abstract}
This study seeks to get a much better understanding of the extent to that info sharing between supply chain cooperative partners within the Asian country producing companies enhances the amount of performances within the business. Therefore, this paper, presents the findings from an empirical study examining the link between info sharing amongst supply chain cooperative partners, product quality performance and business performance in Malaysian producing industry. Few have tried to analyze the link between info sharing amongst supply chain partners and performance. It's aforementioned that info sharing between cooperative supply chain partners has the potential to not solely enhance production potency and effectiveness however conjointly improves bottom-line results. However, the linkage between info sharing amongst supply chain cooperative partners to performance within the manufacturing industry in Malaysia has not been totally self-addressed in empirical studies. to handle this issue, this paper investigates the impact of data sharing between provide chain partners on performance within the Malaysian manufacturing industry using Pearson's correlation, cluster analysis, Friedman's rank check and structural equation modelling. The results of the study reveal that info sharing between cooperative provide chain partners above all seems to be of primary importance and exhibit vital impact on product quality performance and business performance. The findings of the study give a putting demonstration of the importance of implementing effective info sharing between supply chain partners for Malaysian producing industry in enhancing its performance.
\end{abstract}

Keywords: Supply chain management, information sharing, product quality management, business performance, Malaysian manufacturing companies, structural equation modeling. 


\section{Introduction}

Many industries focus on improving their efficiency of their supply chains. One key initiative that is commonly mentioned is information sharing between collaborative partners in a supply chain (Lee, H.L., So, K.C., Tang, C.S. 2000). Information sharing and coordination between the collaborative partners of a supply chain are considered to be an effective strategy for improving its global performance. This paper presents an updated review of current literature examining the impacts of information sharing and collaboration strategies on supply chain performance. Traditional production-distribution schemes have been dramatically changed due to globalization. New partnership relationships among suppliers, manufactures, retailers and other parties have replaced the conventional free market structures (Yu Z., Yan H., Cheng, T. C. 2001). Supply chain management emphasizes the overall and long-time benefit of all parties on the chain through cooperation and information sharing between members (Yu Z., Yan H., Cheng, T. C. 2001).

Supply chain management (SCM) is a network consisting of all parties involved (e.g. manufacturer, supplier, retailer, customer, etc), both downstream and upstream, directly or indirectly, for manufacturing and delivering a product or service to the end customers (Mentzer et al., 2001)(Edwards, Nimako, OwusuManu, \& Conway, 2016). SCM, thus, is a holistic approach to demand, sourcing and procurement, as well as production and logistics process management (Chow et al., 2008; Chopra and Meindl, 2010). The network incorporates various subsystems, activities, relationships and operations (Chandra and Kumar, 2000). An effectively designed and integrated supply chain is considered a source of competitive advantage (Ramdas and Spekman, 2000). A supply chain partnership is a relationship formed between two independent members in supply channels through increased levels of information sharing to achieve specific objectives and benefits in terms of reductions in total costs and inventories. It promises a winwin situation for the members involved (Yu Z., Yan H., Cheng, T. C. 2001). Lee, 
H.L., So, K.C., Tang, C.S. (2000) suggest that information sharing alone could provide significant inventory reduction and cost savings to the manufacturer.

Supply Chain Management (SCM) is connected through the forward and reverse flow of information, materials, services and finances (Stock and Boyer, 2009) in order to enhance the organizational and overall supply chain performance, and likewise to bring high values in terms of quality, cost, speed and flexibility (Chow et al., 2008; Ketchen et al., 2008). Information sharing between members of a supply chain should be increased to reduce the uncertainty (Yu Z., Yan H., Cheng, T. C. 2001). The reason for uncertainties is that perfect information about the system cannot be secured. Uncertainties are caused by delayed deliveries, machine breakdowns, order fluctuations, etc. (Yu Z., Yan H., Cheng, T.C. 2001)(Kaplan, 2017). In supply chain, every member of the chain needs to make a forecast of its downstream site's product demand for its own production planning, inventory control and material requirement planning ( $\mathrm{Yu} \mathrm{Z}$., Yan H., Cheng, T.C. 2001).

This paper explores the role of information sharing between supply chain partners in association with product quality performance and business performance in the Malaysian manufacturing industry. Empirically, the purpose of this study is to present an explicit result on the relationship between information sharing between supply chain partners and performance where other researchers have perhaps known or describe them only implicitly (Kaplan, 2017). Since the link of information sharing between supply chain partners to performance in the manufacturing industry in Malaysia has not been fully addressed in empirical studies, the result of the study would fill a gap that exists in the literature on SCM regarding the importance of information sharing between supply chain partners in Malaysia. The purpose of this paper is to enhance managerial understandings of information sharing between supply chain partners and performance in relation to SCM implementations. The main objectives of this paper are:

- To empirically determine whether information sharing between supply 
chain partners has significant association or impact on product quality performance.

- To empirically discover whether information sharing between supply chain partners has significant association or impact on business performance.

- To empirically assess the importance of each information sharing practice.

\section{Background Study}

Several researchers have implied or empirically established the link between Information Sharing (IS) and Supply Chain Performance (SCP). Lotfi et al. (2013) have investigated and summarized the benefits of IS on SCP. For example, Zhao et. al. (2014) and Lee, So, \& Tang (2000), give evidence of the positive impact of IS on inventory reduction and cost reduction. Fawcett et al. (2007) have investigated two dimensions of IS - connectivity and willingness - which were both found to influence SCP. The study presented in (Ajay \& Maharaj, 2010) reveals that IS has a great impact on the overall cost of running a successful supply chain, and improves the holistic management of supply chain activities. Rashed, Azeem, \& Halim (2010) have explored the combined effect of information and knowledge sharing on supplier's operational performance. In particular, they have showed that information sharing is a prerequisite for knowledge sharing and the close supplier-buyer relationship is a vital factor for escalating the supplier's operational performance. Ahmad and Zailani (2017) investigated the role of Information Quality (IQ) in Supply Chain Management (SCM), considering the IS between buyer and supplier. IQ proved to play an important role in SCM, particularly in the buyer-supplier relationship. Moreover, the IS between buyer and supplier, will result on a big impact to the partnership in term of the business performance.

\section{Theoretical and Conceptual Framework}


Information sharing between supply chain partners program creates value by focusing on key performance gap which in turn helps a company to identify new ideas for a better decision making in order to push the company ahead. Information sharing between supply chain partners makes it easy to identify the gap between where the organization would like to be and where it actually is. This gap provides a measure of the improvements that organization need to make. Ignoring this gap will in turn decrease long-term survival opportunities. The information sharing between supply chain partners process improves processes and helps to meet customer expectation better. As a result its will enhance the company performance against its competitors.

This paper explores the relationship among information sharing between supply chain partners, product quality performance and business performance within the context of the Malaysian manufacturing industry. The proposed conceptual model, as depicted in Figure 1, is based on three main constructs (i) information sharing between supply chain partners (INFOSH); (ii) product quality performance (PQP); and (iii) business performance (BPERF). Essentially, information sharing between supply chain partners represents a manager's assessment of the overall level of information sharing between supply chain partners in SCM initiatives. In addition to improving levels of internal performance, SCM has also been shown to provide benefits in terms of external performance such as market share and profitability (Shetty, 1987).

The conceptual model proposed here utilized information sharing between supply chain partners dimensions derived from studies and documented references (Tan, Kannan, \& Handheld, 1998; Lee, Padmanabhan, and Whang. 1997a, 1997b; Richman, E. \& Zachary, W., 1993). Three dimensions of information sharing between supply chain partners identified from several sources (Tan, Kannan, \& Handheld, 1998; Lee, Padmanabhan, and Whang. 1997a, 1997b; Richman, E. \& Zachary, W., 1993) were considered to relate to distinctive features of information sharing between supply chain partners and are therefore incorporated in the present conceptual model (Figure 1). These information 
sharing between supply chain partners dimensions include: 'Sharing of production information or changes [B3SSCP2], _Sharing of demand forecast information or changes [B3SSCP3] and Sharing of schedules or inventory information or changes [B3SSCP4]. Meanwhile, product quality performance is based on three pertinent dimensions namely product conformance (CONFORM), product performance (PERFORM), product reliability (RELIABLE) and product durability (DURABLE) (Kotler and Armstrong, 1994). Lastly business performance in this study is derived from three important business performance variables comprising of profitability (PROFIT), market share (MKTSH), return on sale (ROS) and return on assets (ROA).

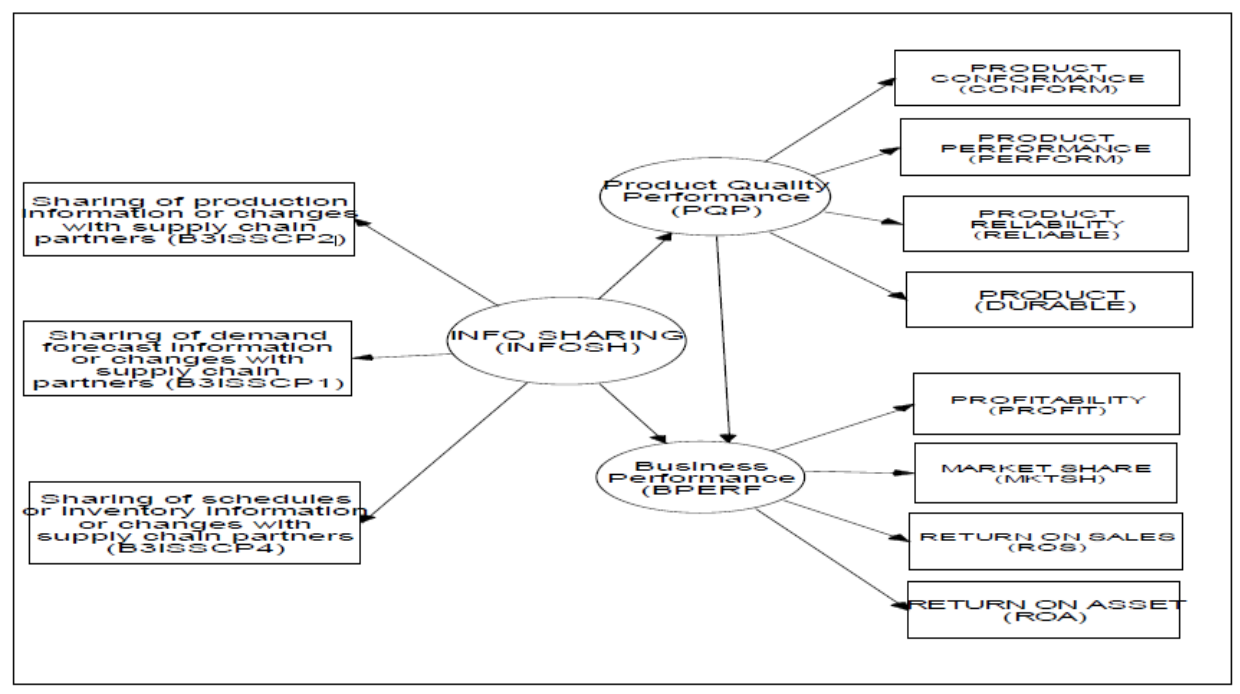

Fig. 1: The conceptual model linking Information sharing, Product quality performance and Business Performance

\section{Hypotheses}

The researchers believe in the notion that information sharing determinants have influences on the overall results such as product quality performance and business 
performance. A structural model is used in this study to analyze the structural effect of information sharing between supply chain partners on performance results. The first hypothesis states that information sharing has positive effect on product quality performance. The second hypothesis states that implementing information sharing between supply chain partners improves business performance. In addition, the last hypothesis suggests that quality performance has a positive structural effect on business performance. Therefore, the following hypotheses are put forward:

H1: Information sharing between supply chain partners has a positive structural effect on product quality performance.

$\mathrm{H} 2$ : Information sharing between supply chain partners has a positive structural effect on business performance.

H3: Product quality performance has a positive structural effect on business performance.

In investigating the structural effect of information sharing between supply chain partners on overall results such as product quality performance and business performance, it is also pertinent to determine the structural loadings of each information sharing between supply chain partners determinant. Therefore, this study also attempts to test the following hypotheses:

H1A: Sharing of production information or changes' has positive structural loading on information sharing between supply chain partners.

H1B: Sharing of demand forecast information or changes' has a positive structural loading on information sharing between supply chain partners.

H1C: Sharing of schedules or inventory information or changes' has a positive structural loading on information sharing between supply chain partners.

More importantly, this study aims to test the overall model fit based on the main null hypothesis:

H0: The overall hypothesized model has a good fit.

For structural modeling, accepting this main hypothesis indicates that the 
model presented adequately reproduce the observed covariance matrix (Bollen, 1989; Joreskog, 1989; Mueller, 1996) and suggesting that the data fit the proposed model.

\section{Research Methodology}

This paper is part of a larger research on SCM and its impact on performances in Malaysian manufacturing companies. The instrument used in this study was a structured survey questionnaire, which was designed to assess the companies in term of the described dimensions. The instrument developed in this study consists of two major parts. The first part comprises several variables measuring SCM practices including information sharing between SCM partners, and the second part comprises several performance measurements. To enable respondents to indicate their answers, seven-point interval scales were used for the questionnaire regarding the level of information sharing between supply chain partners practices in the companies. The respondents were asked to indicate the current practice of the SCM practices including information sharing between supply chain partners based on the scale of 1 (very low degree of current practice) to 7 (very high degree of current practice). In order to capture the multi-dimensional nature of performance measures, this study divided the performances into two types: 1) Product quality performance and 2) Business performance. Due to confidentiality matters and standardization of measurements, the product quality and business performance measures also used a seven-point interval scale, representing a range of agreement on statement whether over the past three years that particular performance is high relative to competitors after implementing information sharing between supply chain partners practice.

Sample companies were chosen from manufacturing companies in Malaysia (the sampling frame is derived from the Federation of Malaysian Manufacturers Directory-FMM). Two hundred responses were received from a total of 300 sample companies chosen which representing 67 percent response rate. The 
primary purpose of the research is to measure senior production managers' and SCM managers" or perception of information sharing and to gain insight into the benefits of implementing information sharing in the manufacturing industry. The goal is to understand and determine measures of information sharing that can enhance product quality performance and bottom line result (profitability, market share, return on sale and return on asset). Face to face interviews with production managers were carried out to ensure the information accuracy, validating the outcome of analysis and developing an understanding of practical aspects of information sharing principles adoption.

Table 1: Descriptive Statistics of Critical Variables.

\begin{tabular}{|c|c|c|c|c|c|}
\hline \multirow{2}{*}{$\begin{array}{l}\text { Information sharing } \\
\text { between supply chain } \\
\text { partners: }\end{array}$} & \multirow[b]{2}{*}{ Mean } & \multirow{2}{*}{$\begin{array}{l}\text { Std. } \\
\text { Dev. }\end{array}$} & \multicolumn{3}{|c|}{$\begin{array}{l}\text { Exploratory Factor Analysis - } \\
\text { EFA(Varimax Rotation) }\end{array}$} \\
\hline & & & $\begin{array}{r}\text { Factor } \\
\text { Loadings1 } \\
(\mathrm{PQP})\end{array}$ & \begin{tabular}{|c} 
Factor \\
Loadings \\
2 \\
(BPERF)
\end{tabular} & \begin{tabular}{|c} 
Factor \\
Loadings \\
$\mathbf{3}$ \\
(INFOSH)
\end{tabular} \\
\hline $\begin{array}{c}\text { Sharing of production } \\
\text { information or changes } \\
\text { [B3SSCP2] }\end{array}$ & $\begin{array}{c}4.675 \\
0\end{array}$ & 1.41754 & .206 & .241 & .872 \\
\hline $\begin{array}{c}\text { Sharing of demand forecast } \\
\text { information or changes } \\
\text { [B3SSCP3] }\end{array}$ & $\begin{array}{c}4.730 \\
0\end{array}$ & 1.51611 & .182 & .158 & .919 \\
\hline $\begin{array}{l}\text { Sharing of schedules or } \\
\text { inventory information or } \\
\text { changes [B3SSCP4] }\end{array}$ & $\begin{array}{c}4.505 \\
0\end{array}$ & 1.53026 & .232 & .114 & .885 \\
\hline \multicolumn{6}{|c|}{ Product Quality Performance: } \\
\hline $\begin{array}{l}\text { Product Conformance } \\
\text { (CONFORM) }\end{array}$ & $\begin{array}{c}5.465 \\
0\end{array}$ & 1.06510 & .867 & .299 & .208 \\
\hline $\begin{array}{c}\text { Product Performance } \\
\text { (PERFORM) }\end{array}$ & $\begin{array}{c}5.545 \\
0\end{array}$ & 1.03602 & .839 & .348 & .228 \\
\hline $\begin{array}{l}\text { Product Reliability } \\
\text { (RELIABLE) }\end{array}$ & $\begin{array}{c}5.575 \\
0\end{array}$ & 1.09102 & .855 & .312 & .197 \\
\hline
\end{tabular}




\begin{tabular}{|c|c|c|c|c|c|} 
& & & & \\
\hline $\begin{array}{c}\text { Product Durability } \\
\text { (DURABLE) }\end{array}$ & $\begin{array}{c}5.390 \\
0\end{array}$ & 1.12438 & .855 & .282 & .229 \\
\hline \multicolumn{5}{|c|}{ Business Performance: } & .136 \\
\hline Profitability (PROFIT) & $\begin{array}{c}4.955 \\
0\end{array}$ & 1.20007 & .254 & .814 & .205 \\
\hline Market Share (MKTSH) & $\begin{array}{c}4.690 \\
0\end{array}$ & 1.43324 & .264 & .794 & .154 \\
\hline Return on Sales (ROS) & $\begin{array}{c}4.890 \\
0\end{array}$ & 1.23105 & .330 & .853 & .157 \\
\hline Return on Assets (ROA) & $\begin{array}{c}4.835 \\
0\end{array}$ & 1.15952 & .300 & .859 & \\
\hline
\end{tabular}

Table 2: Factor Analysis and Reliability Test

\begin{tabular}{|c|c|c|c|c|c|c|}
\hline \multirow{2}{*}{ CONSTRUCT } & \multicolumn{3}{|c|}{$\begin{array}{c}\text { Exploratory Factor Analysis -EFA } \\
\text { (Varimax Rotation) }\end{array}$} & $\begin{array}{c}\text { Confirmatory } \\
\text { Factor Analysis } \\
-\end{array}$ & $\begin{array}{c}\text { Reliability } \\
\text { Test }\end{array}$ \\
\cline { 2 - 7 } & $\begin{array}{c}\text { Eigenvalu } \\
\mathrm{e}\end{array}$ & $\begin{array}{c}\text { Cariance } \\
\text { Explained }\end{array}$ & $\begin{array}{c}\text { Cummulative } \\
\text { Explained }\end{array}$ & GFI & CFI & Alpha \\
\hline $\begin{array}{c}\text { Information } \\
\text { sharing }\end{array}$ & 3.379 & 30.719 & 30.719 & 0.902 & 0.905 & 0.923 \\
\hline $\begin{array}{c}\text { Product Quality } \\
\text { Performance }\end{array}$ & 3.243 & 29.484 & 60.203 & 0.984 & 0.995 & 0.951 \\
\hline $\begin{array}{c}\text { Business } \\
\text { Performance }\end{array}$ & 2.682 & 24.384 & 84.586 & 0.998 & 0.999 & 0.912 \\
\hline
\end{tabular}

Extraction Method: Principal Component Analysis.

Rotation Method: Varimax with Kaiser Normalization $(\mathrm{KMO}=0.903)$

Exploratory factor analysis, confirmatory factor analysis and Cronbach's reliability analysis were used to select and assess the final items that would be used for hypothesis testing. The critical variables of information sharing between 
supply chain partners in this study had content validity because an extensive review of the literature was conducted in selecting the measurement items. The information sharing between supply chain partners determinants in this study were adopted from prominent studies or sources (Tan, Kannan, \& Handheld,1998; Lee, Padmanabhan, and Whang. 1997a,1997b; Richman, E. \& Zachary, W., 1993). As the initial data analysis, the four determinants of information sharing between supply chain partners were subjected to validity and reliability tests. Exploratory factor analysis was conducted to investigate whether the constructs as described in the literature fits the factors derived from the factor analysis. The result from the factor analysis indicates that the KMO (Kaiser-Meyer-Olkin) measure is 0.903 with significant chi-square value (Barlett's Test of Sphericity $=$ 2023 , probability value $=0.000$ ). The value of $\mathrm{KMO}$ in this analysis surpasses the threshold value of 0.50 as recommended by Hair et. al (1998). All variables or determinants exhibit high factor loadings and fall into the designated factors. This result provides evidence to support the theoretical conceptualization of each construct. In addition, confirmatory factor analysis (CFA) or a measurement model using AMOS 5 was employed for examining construct validity of each scale by assessing how well the individual item measured the scale (Ahire et al., 1996). The goodness of fit indices (GFI) and comparative fit index (CFI) of the exogenous determinants exceeded the 0.90 criterion suggested by Hair et al. (1998), hence, establishing the construct validity (see Table 2). The reliability analysis was conducted by calculating the Cronbach's alpha for the main constructs. The result shows that the Cronbach's alpha measures for the main constructs exceeds the threshold point of 0.70 suggested by Nunnally (1978). Alpha coefficients for information sharing between supply chain partners scales and performance scales ranged between 0.912 and 0.951 after the alpha maximization processes were carried out (Table 2).

\section{Preliminary Results}




\subsection{Correlations between information sharing between supply chain partners, product quality performance and business performance}

As a preliminary analysis, Table 3 exhibits correlation among the information sharing between supply chain partners practices as well as the multi collinearity statistics. The result indicates that the information sharing between supply chain partners practices have significant correlations with one another. In addition, it suggests that those practices complement each other and need to be implemented in a holistic manner. Furthermore, the collinearity test did not indicate any multicollinearity problem. Table 4 and Table 5 exhibit Pearson's correlations between information sharing between supply chain partners and product quality performance as well as business performance. Most of the product quality performance indicators have high correlations with information sharing between supply chain partners especially with determinants namely 'Sharing of production information or changes [B3SSCP2], _Sharing of demand forecast information or changes [B3SSCP3] and Sharing of schedules or inventory information or changes [B3SSCP4]. Specifically, product conformance, product performance and product quality performance have significant correlations with all the three information sharing determinants. On the other hand, business performance measures such as profitability, return on assets, return on sales and market share have significant correlations with information sharing. These findings are consistent with several previous studies that proclaimed better organizational transformations as a result of information sharing initiatives (Tan, Kannan, \& Handheld,1998; Lee, Padmanabhan, and Whang. 1997a,1997b, Schaffer \& Thompson 1992; Richman, E. \& Zachary, W., 1993).

Table 3: Pearson's correlation among information sharing and collinearity statistics

\begin{tabular}{|c|c|c|c|c|}
\hline $\begin{array}{c}\text { Information sharing } \\
\text { between supply }\end{array}$ & 1 & 2 & 3 & $\begin{array}{c}\text { Collinearity } \\
\text { Statistics }\end{array}$ \\
\hline
\end{tabular}




\begin{tabular}{|c|c|c|c|c|c|c|}
\hline \multicolumn{2}{|r|}{$\begin{array}{l}\text { chain partners } \\
\text { Variables }\end{array}$} & \multirow[b]{2}{*}{1} & & & \multirow{2}{*}{$\begin{array}{c}\text { Tolerance } \\
.287\end{array}$} & \multirow{2}{*}{$\begin{array}{r}\text { VIF } \\
3.488\end{array}$} \\
\hline 1 & $\begin{array}{c}\text { Sharing of } \\
\text { production } \\
\text { information or } \\
\text { changes } \\
\text { [B3SSCP2] }\end{array}$ & & & & & \\
\hline 2 & $\begin{array}{c}\text { Sharing of } \\
\text { demand } \\
\text { forecast } \\
\text { information or } \\
\text { changes } \\
\text { [B3SSCP3] }\end{array}$ & $.833(* *)$ & 1 & & .228 & 4.388 \\
\hline 3 & $\begin{array}{l}\text { Sharing of } \\
\text { schedules or } \\
\text { inventor } \\
\text { information or } \\
\text { changes } \\
\text { [B3SSCP4] }\end{array}$ & $.757(* *)$ & $.813(* *)$ & 1 & .319 & 3.139 \\
\hline & $\begin{array}{l}\text { 1. *P } \quad 0.05, \\
* * \mathrm{P} \quad 0.012 .\end{array}$ & $\begin{array}{r}\text { All t-test } \\
\text { tai }\end{array}$ & $\begin{array}{l}\text { are two- } \\
\text { d }\end{array}$ & & & \\
\hline
\end{tabular}

Table 4: Pearson correlation between information sharing and product quality performance

\begin{tabular}{|c|c|c|c|c|c|}
\hline \multicolumn{2}{|c|}{$\begin{array}{l}\text { Information sharing between } \\
\text { supply chain partners }\end{array}$} & \multirow{2}{*}{$\begin{array}{c}\begin{array}{c}\text { Product } \\
\text { Conformance }\end{array} \\
\\
.437(* *) \\
\end{array}$} & \multirow{2}{*}{\begin{tabular}{|c|}
$\begin{array}{c}\text { Product } \\
\text { Performance }\end{array}$ \\
\\
$.460(* *)$ \\
\end{tabular}} & \multirow{2}{*}{\begin{tabular}{|c}
$\begin{array}{c}\text { Product } \\
\text { Reliability }\end{array}$ \\
\\
$.433(* *)$ \\
\end{tabular}} & \multirow{2}{*}{\begin{tabular}{|}
$\begin{array}{c}\text { Product } \\
\text { Durability }\end{array}$ \\
$.430(* *)$ \\
\end{tabular}} \\
\hline 1 & $\begin{array}{l}\text { Sharing of production } \\
\text { information or changes } \\
\text { [B3SSCP2] }\end{array}$ & & & & \\
\hline 2 & $\begin{array}{l}\text { Sharing of demand forecast } \\
\text { information or changes } \\
\text { [B3SSCP3] }\end{array}$ & $.389(* *)$ & $.411(* *)$ & $.398(* *)$ & $.416(* *)$ \\
\hline 3 & $\begin{array}{l}\text { Sharing of schedules or } \\
\text { inventory } \\
\text { information or changes } \\
\text { [B3SSCP4] }\end{array}$ & $.422(* *)$ & $.434(* *)$ & $.388(* *)$ & $.437(* *)$ \\
\hline
\end{tabular}


** Correlation is significant at the 0.01 level (2-tailed). * Correlation is significant at the 0.05 level (2-tailed).

Table 5 Pearson correlation between information sharing and business performance

\begin{tabular}{|l|c|c|c|c|c|}
\hline \multicolumn{2}{|c|}{$\begin{array}{c}\text { Information sharing between } \\
\text { supply chain partners }\end{array}$} & Profitability & $\begin{array}{c}\text { Market } \\
\text { share }\end{array}$ & $\begin{array}{c}\text { Return on } \\
\text { Sales }\end{array}$ & Return on \\
Assets \\
\hline 1 & $\begin{array}{c}\text { Sharing of production } \\
\text { information or } \\
\text { changes [B3SSCP2] }\end{array}$ & $.367(* *)$ & $.410(* *)$ & $.406(* *)$ & $.398(* *)$ \\
\hline 2 & $\begin{array}{c}\text { Sharing of demand forecast } \\
\text { information or changes } \\
{[\text { B3SSCP3] }}\end{array}$ & $.297(* *)$ & $.364(* *)$ & $.339(* *)$ & $.332(* *)$ \\
\hline 3 & $\begin{array}{c}\text { Sharing of schedules or } \\
\text { inventory } \\
\text { information or changes } \\
\text { [B3SSCP4] }\end{array}$ & $.283(* *)$ & $.324(* *)$ & $.315(* *)$ & $.322(* *)$ \\
\hline
\end{tabular}

** Correlation is significant at the 0.01 level (2-tailed).

* Correlation is significant at the 0.05 level (2-tailed).

\subsection{Cluster Analysis and Friedman's Test}

This study also tries to highlight which of information sharing determinants are more emphasized or prioritized by successful companies. Since product quality performance and business performance are very importance bottom-line outcomes, therefore the classifications are based on average product quality performance and business performance clustering. Two cluster analyses were carried out to further explore on the segmentation of manufacturing companies in this study. As an example, Table 6 and Table 7 highlight further information about the cluster analysis result. The first cluster analysis categorized companies into one of two groups:

- Excellentl| product quality producers

- $\quad$ Averagell product quality producers 
Table 6 Rankings of information sharing determinants based on product quality performance clustering using Friedman's rank test

\begin{tabular}{|c|c|c|c|c|c|c|c|c|}
\hline \multirow{2}{*}{$\begin{array}{c}\text { Information } \\
\text { sharing between } \\
\text { supply chain } \\
\text { partners }\end{array}$} & \multicolumn{4}{|c|}{$\begin{array}{c}\text { High product quality } \\
\text { producers } \\
(\mathrm{n}=116, \text { chi-square }=6.680, \\
\text { significant }=0.035 \text {, overall } \\
\text { cluster's } \\
\text { mean }=5.097)\end{array}$} & \multicolumn{4}{|c|}{$\begin{array}{c}\text { Low product quality } \\
\text { producers } \\
(\mathrm{n}=84, \text { chi-square }= \\
7.541, \\
\text { significant }=0.023 \text {, overall } \\
\text { cluster's } \\
\text { mean }=3.999)\end{array}$} \\
\hline & $\begin{array}{c}\text { Friedman' } \\
\text { s } \\
\text { Test }\end{array}$ & Rank & $\underset{\mathbf{n}}{\mathbf{M e a}}$ & $\begin{array}{l}\text { Std } \\
\text { Dev }\end{array}$ & $\begin{array}{c}\text { Friedman' } \\
\mathbf{S} \\
\text { Test }\end{array}$ & Rank & $\begin{array}{c}\text { Mea } \\
\mathbf{n}\end{array}$ & $\begin{array}{l}\text { Std } \\
\text { Dev }\end{array}$ \\
\hline $\begin{array}{c}\text { Sharing of } \\
\text { production } \\
\text { information or } \\
\text { changes } \\
\text { [B3SSCP2] }\end{array}$ & 1.98 & 2 & $\begin{array}{c}5.10 \\
3\end{array}$ & 1.301 & 2.10 & 1 & $\begin{array}{c}4.08 \\
3\end{array}$ & 1.364 \\
\hline 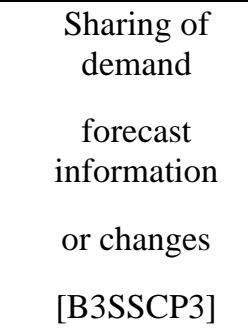 & 2.12 & 1 & $\begin{array}{c}5.19 \\
8\end{array}$ & 1.385 & 2.07 & 2 & $\begin{array}{c}4.08 \\
3\end{array}$ & 1.458 \\
\hline $\begin{array}{l}\text { Sharing of } \\
\text { schedules or } \\
\text { inventory } \\
\text { information or } \\
\text { changes } \\
\text { [B3SSCP4] }\end{array}$ & 1.90 & 3 & $\begin{array}{c}4.99 \\
1\end{array}$ & 1.465 & 1.83 & 3 & $\begin{array}{c}3.83 \\
3\end{array}$ & 1.361 \\
\hline
\end{tabular}

Since business performance is also a very importance bottom-line outcome, therefore the second classification is based on average business performance 
clustering. This second cluster analysis categorized manufacturing companies into two groups:

- High business performance achievers

- Averagell business performance achievers

From the result, we can also infer that the higher level of information sharing between supply chain partners is more realized in -Excellentl product quality producers and -High\| business performance achieversll. These companies put high priorities on 'Sharing of production information or changes, _Sharing of demand forecast information or changes and Sharing of schedules or inventory information or changes. Nonetheless, the findings highlight the importance of information sharing between supply chain partners in both clusters.

Table 7: Rankings of information sharing determinants based on business performance clustering using Friedman's rank test

\begin{tabular}{|c|c|c|c|c|c|c|c|c|}
\hline \multirow{2}{*}{$\begin{array}{c}\text { Information } \\
\text { sharing } \\
\text { between supply } \\
\text { chain } \\
\text { partners }\end{array}$} & \multicolumn{4}{|c|}{\begin{tabular}{|c|} 
High business performance \\
companies \\
(n=101, chi-square $=10.622$ \\
significant $=0.005$, overall \\
cluster's \\
mean $=5.155)$ \\
\end{tabular}} & \multicolumn{4}{|c|}{$\begin{array}{c}\text { Low business performance } \\
\text { companies } \\
(\mathrm{n}=99, \text { chi-square }=3.889, \\
\text { significant }=0.143, \\
\text { overall cluster's mean }=4.107)\end{array}$} \\
\hline & \begin{tabular}{|c} 
Friedman' \\
$\mathbf{s}$ \\
Test \\
\end{tabular} & Rank & Mean & $\begin{array}{l}\text { Std } \\
\text { Dev }\end{array}$ & \begin{tabular}{|c|} 
Friedman' \\
$\mathbf{s}$ \\
Test \\
\end{tabular} & Rank & Mean & $\begin{array}{l}\text { Std } \\
\text { Dev }\end{array}$ \\
\hline $\begin{array}{l}\text { Sharing of } \\
\text { production } \\
\text { information or } \\
\text { changes } \\
\text { [B3SSCP2] }\end{array}$ & 2.07 & 2 & 5.257 & $\begin{array}{c}1.33 \\
9\end{array}$ & 1.98 & 2 & 4.081 & 1.243 \\
\hline $\begin{array}{l}\text { Sharing of } \\
\text { demand } \\
\text { forecast } \\
\text { information } \\
\text { or changes } \\
\text { [B3SSCP3] }\end{array}$ & 2.09 & 1 & 5.218 & $\begin{array}{c}1.41 \\
1\end{array}$ & 2.11 & 1 & 4.232 & 1.463 \\
\hline
\end{tabular}




\begin{tabular}{|c|l|l|l|l|l|l|l|l|}
\hline $\begin{array}{c}\text { Sharing of } \\
\text { schedules } \\
\text { or inventory } \\
\text { information or } \\
\text { changes } \\
\text { [B3SSCP4] }\end{array}$ & 1.83 & 3 & 4.990 & $\begin{array}{c}1.55 \\
9\end{array}$ & 1.91 & 3 & 4.010 & 1.336 \\
\hline
\end{tabular}

\section{The Result of the Structural Equation Modeling}

The relationship between information sharing between supply chain partners, product quality performance and business performance is depicted in the structural equation modeling (SEM). A structural model can be viewed as simultaneous linkages that allow a researcher to determine the relative strength of relationships between variables. In this statistical analysis, we would like the model developed to fit the data, therefore the acceptance of the null hypothesis of the overall model is expected. Hence, in this test of goodness of fit for the SEM, the probability we are looking for should be higher than 0.05 . The findings of SEM model indicate that the resulting Chi-square value is 38.465 with 41 degrees of freedom and p-value of 0.584 (Figure 2). This result supports the null hypothesis that the SEM model has a good fit ( $\mathrm{H} 0$ ). The p-value is considerably substantial ( $\mathrm{p}$-value $>0.05$ ), in supporting the main null hypothesis that the overall model fits the data.

In addition, other statistical structural indices such as Bentler comparative fit index CFI (0.999), Normed fit index NFI (0.981) and Goodness of fit index GFI (0.966) further suggest that the model has a satisfactory fit (Table 8). Since the probability value and structural modeling indices are well above the recommended level, the model is considered to be a reasonable representation of the data (Hair et al., 1998). The direct structural effect of information sharing between supply chain partners on product quality performance $(0.505)$, the direct structural effect of information sharing between supply chain partners on business performance (0.117) and the indirect effect of information sharing between supply chain partners on business performance through product quality 
performance (0.624) are considered high given the complex causal linkages, suggesting the importance of information sharing between supply chain partners practices especially 'sharing of demand forecast information or changes', 'sharing of production information or changes" and "sharing of schedule or inventory information or changes' in improving operational and ultimately business performance in Malaysian the manufacturing industry. Therefore, we have enough evidence to accept the proposition that information sharing between supply chain partners has positive and significant structural effect on product quality performance (H1). In addition, information sharing between supply chain partners has significant direct effect on business performance (H 2$)$ and finally product quality performance has significant direct effect on business performance (H 3).

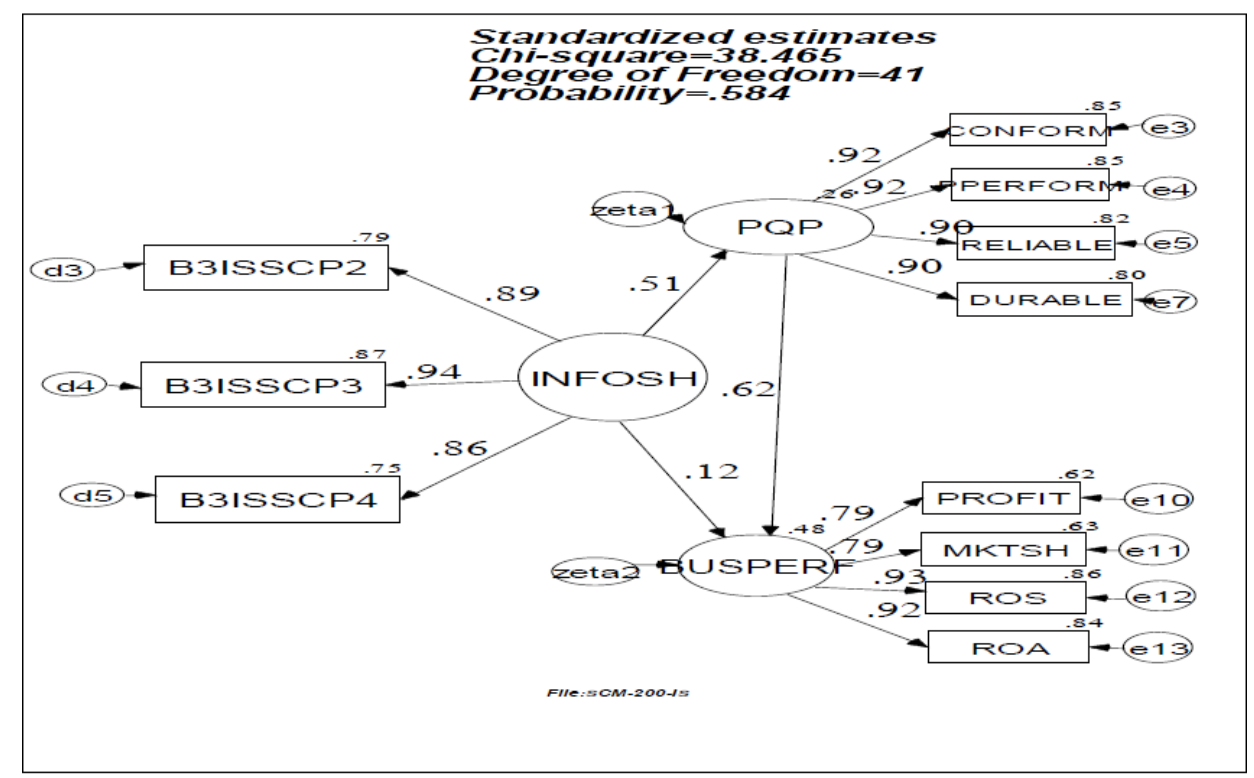

Fig. 2: The structural model showing the structural linkage between information sharing, product quality performance and business performance.

Using SEM, the researchers investigate the impact of information sharing on product quality perform ance and business performance simultaneous. In addition, SEM is able to measure the magnitude and contribution between those constructs. 
The SEM result suggests that information sharing between supply chain partners has positive effects on product quality performance and ultimately improve business performance.

Table 8: Measurement results of the SEM model

\begin{tabular}{|l|l|l|}
\hline Statistics & Model Values & $\begin{array}{l}\text { Recommended } * \\
\text { values for good fit }\end{array}$ \\
\hline Chi square & 38.465 & \\
\hline Probability Level & 0.584 & $\geq 0.05$ \\
\hline Degree of Freedom & 41 & \\
\hline $2 /$ df & 0.8142 & $\leq 3.00$ \\
\hline Bollen (1989) Incremental Fit Index (IFI) & 0.999 & $\geq 0.90$ \\
\hline Tucker \& Lewis (1973) TLI & 0.999 & $\geq 0.90$ \\
\hline Bentler (1988) comparative fit model (CFI) & 0.999 & $\geq 0.90$ \\
\hline Normed fit index (NFI) & 0.981 & $\geq 0.90$ \\
\hline Goodness of fit index (GFI) & 0.966 & $\geq 0.90$ \\
\hline
\end{tabular}

*Chau (1997)

Table 9 Measurement results of the SEM model

\begin{tabular}{|c|c|c|c|c|}
\hline $\begin{array}{l}\text { Constructs and } \\
\text { indicators }\end{array}$ & \begin{tabular}{|c|} 
Std. \\
Loadings
\end{tabular} & $\begin{array}{c}\text { Std. } \\
\text { errors }\end{array}$ & $\begin{array}{c}\text { Critical } \\
\text { Ratio }\end{array}$ & \begin{tabular}{|l|}
$\begin{array}{l}\text { Probability } \\
\text { (significant) }\end{array}$ \\
\end{tabular} \\
\hline \multicolumn{5}{|l|}{$\begin{array}{l}\text { a. INFORMATION SHARING } \\
\text { BETWEEN SUPPLY CHAIN } \\
\text { PARTNERS ( INFO) }\end{array}$} \\
\hline $\begin{array}{c}\text { Sharing of production information or } \\
\text { changes [B3SSCP2] }\end{array}$ & 0.890 & 0.046 & 19.417 & 0.000 \\
\hline $\begin{array}{l}\text { Sharing of demand forecast } \\
\text { information or changes [B3SSCP3] }\end{array}$ & 0.935 & 0.058 & 19.417 & 0.000 \\
\hline $\begin{array}{l}\text { Sharing of schedules or inventory } \\
\text { information or changes [B3SSCP4] }\end{array}$ & 0.863 & 0.061 & 17.029 & 0.000 \\
\hline \multicolumn{5}{|l|}{ b. Product Quality Performance (PQP) } \\
\hline Product Conformance & 0.922 & 0.047 & 21.237 & 0.000 \\
\hline Product Performance & 0.921 & 0.046 & 21.265 & 0.000 \\
\hline Product Reliability & 0.903 & 0.049 & 21.265 & 0.000 \\
\hline Product Durability & 0.896 & 0.052 & 19.768 & 0.000 \\
\hline \multicolumn{5}{|l|}{ c. Business Performance (BPERF) } \\
\hline Profitability & 0.788 & 0.055 & 15.189 & 0.000 \\
\hline
\end{tabular}




\begin{tabular}{|c|c|c|c|c|}
\hline Market Share & 0.794 & 0.097 & 12.390 & 0.000 \\
\hline Return on sales & 0.927 & 0.079 & 15.189 & 0.000 \\
\hline Return on assets & 0.915 & 0.075 & 14.960 & 0.000 \\
\hline $\begin{array}{c}\text { a. } \\
\text { (ii) Exogenous/endogenous Path }\end{array}$ & & & & \\
\hline INFOSH PQP [ $H_{1}$ is supported] & 0.505 & 0.046 & 7.345 & 0.000 \\
\hline $\begin{array}{c}\text { b. INFOSH BPERF [ } H_{2} \text { is } \\
\text { supported] }\end{array}$ & 0.117 & 0.055 & 1.725 & 0.085 \\
\hline c. PQP BPERF [ $H_{3}$ is supported] & 0.624 & 0.085 & 8.799 & 0.000 \\
\hline
\end{tabular}

Looking at the loadings of the information sharing between supply chain partners determinants (Table 9) on the main construct, we can see that sharing of demand forecast information or change $(0.935)$ has the highest contribution towards information sharing between supply chain partners and it is followed by _sharing of production information or changes“ $(0.935)$ and _sharing of schedule or inventory information or changes ${ }^{6}(0.935)$. All of these indicators have significant probability values (critical values 2.00), giving statistical evidence that their contributions towards information sharing between supply chain partners main construct are significant and positive. We can obviously suggest that information sharing between supply chain partners can help manufacturing companies to improve their product quality performance and subsequently, it is safe to state that information sharing between supply chain partners can ultimately enhance business performance of the manufacturing industry in Malaysia in the long run.

Thus, a manufacturing company can enhance its product quality performance and business performance by integrating information sharing between supply chain partners. The examination of residuals also reveals that variances among variables of the construct are perfectly explained by the respective constructs. The result highlights the unique contribution of information sharing between supply chain partners on product quality performance and business performance and supports the notion that the structural model has a satisfactory fit. Obviously, the result suggests that information sharing between supply chain partners would 
enhance product quality performance and ultimately improve business performance in manufacturing companies in Malaysia.

\section{Implications and Recommendations}

The research findings of this study have several implications for academics and others involved in theory building. Firstly, this study extends previous supply chain practice frameworks in Western countries by considering different key dimensions of SCM practices in Malaysian manufacturing firms. The research data strongly argue that for strategic SCM to be successful, scholars must not focus on one particular inhibitor, but rather consider customer integration, supplier integration and internal functions in combination. Secondly, this study is one of the first few papers to examine the relationship between SCM and Information Sharing using the highly rigorous method of SEM. The presence of the relationship stresses the role of learning in implementing supply chain management practices over time. The learning process can help firms to develop capabilities that have creative value and are hard to imitate. In addition to the theoretical implications for academics, the findings of this study may also have implications for managers and practitioners, especially for those in manufacturing firms. First, manufacturing firms face difficulties in selecting suitable and effective SCM concepts and methods (Li et al., 2006). The study found evidence of some highly varied and progressive information sharing practices amongst manufacturing firms. Therefore, it provides managers with a useful tool to evaluate current supply chain practices and recommends simple but effective and efficient practices to perform vitally important supply chain functions aimed at enhancing performance capabilities.

Second, the results of the study support the claim that the execution of SCM positively affects the performance capabilities of manufacturing firms in a developing country. Therefore, managers can easily gain a general overview of the implementation of suitable SCM information sharing practices for enhanced 
performance capabilities. The results suggest that information sharing is a leading capability. From the findings, a company can invest in this capability to develop a competitive differentiation strategy for sustainable performance, rather than investing in a series of practices and capabilities that may incur more costs. Accordingly, managers must not only develop unique capabilities internal to the firm, but they must recognise the combined effects of SCM practices that can generate a total impact on performance capabilities.

The benefit of information sharing lies in the manufacturer's capability to react to the retailer's needs via the knowledge of the retailer's inventory levels to help reduce uncertainties in the demand process faced by the manufacturer (Lee, H.L., So, K.C., Tang, C.S. 2000). The manufacturer can benefit from obtaining information about the demand from the retailer because it would enable the manufacturer to derive a more accurate forecast for future orders placed by the retailer (Lee, H.L., So, K.C., Tang, C.S. 2000). The primary benefit of sharing demand and inventory information is a reduction in the bullwhip effect and, consequently, a reduction in inventory holding and shortage costs within the supply chain (Forrester, 1958; Sterman, 1989; Lee et al., 1997a, 1997b)

This paper tries to investigate the structural relationship between information sharing between supply chain partners, product quality performance and business performance in the Malaysian manufacturing industry. It is important to note that by using SEM, the author is focused on examining the strength of the relationships between information sharing between supply chain partners, product quality performance and business performance as a whole, and not on the individual effect of the three information sharing practices. The results of the study assist in understandings on how information sharing between supply chain partners may influence product quality performance and business performance. This study leads to several main conclusions:

- Information sharing between supply chain partners determinants namely "sharing of demand forecast information or changes", "sharing of production information or changes' and sharing of schedule or inventory 
information or changes' have positive and direct effects on product quality performance.

- Information sharing between supply chain partners has positive and indirect effects on business performance through product quality performance.

- Product quality performance (especially product conformance, product performance, product reliability and product durability) has positive and direct effects on business performance (namely profitability, market share return on sales and return on assets).

- The Malaysian Information sharing between collaborative supply chain partners Index $(\mathrm{MBI}=60.63)$ for the manufacturing industry is considered average indicating moderate information sharing between supply chain partners involvement and initiatives.

The conclusion emerging from this study is that information sharing between supply chain partners will ultimately results in positive gains. The results validate some of the key linkages and support beliefs and evidence by other researchers of the relationships between information sharing between supply chain partners and performance. It is also important to note that this study attempts to enrich the literature review and make a contribution in information sharing between supply chain partners and SCM-related studies. In addition, its purpose has been to make explicit what other researchers have perhaps known implicitly but without solid empirical measurements. The empirical results support long-standing beliefs and anecdotal evidence by researchers about the relationships between the exogenous (information sharing between supply chain partners) and endogenous results (performances), and lend credibility to causal hypotheses that improving internal process leads to improvements in external performance results. This study to some extent helps in resolving controversy about the magnitude and measurements of performance gains from information sharing between supply chain partners. By strengthening information sharing between supply chain 
partners, improved performance is likely to occur.

This study contributes to both practical and theoretical knowledge, but the results contain several potential limitations. First, the sample population of this study was narrowly focused on Malaysian manufacturing firms in several locations and may not be a true representation of all Malaysian manufacturers. It is of great importance to include more service organizations in future research. Second, this study is parsimonious in that the data were collected from a single informant in each firm. Future research should collect survey information from multiple respondents from each participating firm using the instrument developed in this study to enhance the reliability of the research findings. Finally, SCM has evolved rapidly from being a one-dimensional subject with a narrow focus on logistics and the physical aspects of material flow into a multifaceted theory encompassing every effort involved in producing and delivering a final product from the supplier to the customer. Other factors within the domain of supply chain practices and performance capabilities are required for further exploration. Further research into these would contribute to the knowledge of supply chains and firm capabilities (especially concerning firms in the manufacturing industry) and the relationships among them. The paper will be of particular interest to practicing production managers or top level managers as it suggests the importance information sharing between supply chain partners in the Malaysian manufacturing industry. The result indicates that manufacturing companies should emphasize greater attention to the degree of information sharing between supply chain partners programs in enhancing bottom-line performance.

\section{References}

Ahire, S.L., Golhar, D. Y. \& Waller, M. A. (1996) Development and validation of TQM implementation constructs, Decision Sciences., 27(1), pg 2355.Anonymous. 1995, ISO and Total Quality, International Journal of Health Care Quality Assurance, 8(4), 34-35. 
Ahmad, B.N., \& Zailani, S. (2017). The Effect of Information Quality on BuyerSupplier Relationships: A Conceptual Framework. 7th Global Conference on Business \& Economics Oct. 3-4, Rome, Italy

Ajay, A., \& Maharaj, M. (2010). Effects of Information Sharing within Supply Chains. SACLA (pp. 35-42). Pretoria: University of Pretoria.

Arawati Agus \& Za'faran Hassan. (2000). Exploring the relationship between the length of TQM adoption and financial performance: An empirical study in Malaysia, International Journal of Management, September, 17(3), 323-333.

Arawati Agus. (2001). A linear structural modelling of total quality management practices in manufacturing companies in Malaysia. Total Quality Management, $12(5), 561-573$.

Black, K. (2001). Business Statistics: Contemporary decision-making (SouthWestern College Publishing, Thompson Learning, USA)

Bickman, L. (2000). Summing up program theory. In P. Rogers, T. Hacsi, A. Petrosino, \& T. Huebner (Eds.), New Directions for Evaluation, 87, 103-112

Bollen, Kenneth A. 1989. Structural equations with latent variables. New York: John Wiley and Sons.

Chandra, K., \& Kumar, S. (2000). Supply chain management in theory and practice: A passing fad or a fundamental change? Industrial Management \& Data System, 100(3), 100-113.

Chopra, S., \& Meindl, P. (2010). Supply chain management: Strategy, planning, and operation (4th ed.). Upper Saddle River, New Jersey: Pearson Education, Inc. 
Chow, W. S., Madu, C. N., Kuei, C-H., Lu, M. H., Lin, C., \& Tseng, H. (2008). Supply chain management in the US and Taiwan: An empirical study. Omega: The International Journal of Management Science, 36, 665-679.

Cronbach, L.J. (1951). Coefficient alpha and the internal structure of tests. Psychometrika. 16, 297-334.

Edwards, D., Nimako, S., Owusu-Manu, D., \& Conway, C. (2016). Antecedents of supplier relation quality in the Ghanaian construction supply chain. Journal of Construction Supply Chain Management, 6(1), 1-18.

Fawcett, S. E., Osterhaus, P., Magnan, G.M., Brau, J.C., \& McCarter, M.W. (2007). Information sharing and supply chain performance: the role of connectivity and willingness. Supply Chain Management: An International Journal, 12(5), 358-368.

Fink, R. (1988), "Group therapy", Financial World, Vol. 162 No.19, pp.42-8.

Forrester, J.W. (1958), Industrial dynamics - a major breakthrough for decision making. Harvard Business Review, 36, 37-66.

Fornell C., Johnson M. D., Anderson, E. W., Cha J. \& Bryant, B. E. (1996). The American Customer Satisfaction Index: Nature, Purpose and findings. Journal of marketing. Vol. 60 (October 1996), 7-18.

Garvin, D.A. (1993), "Building a learning organization", Harvard Business Review, Vol. 71 No.4, pp.78-92.

Hair, J.F., Anderson, R.E., Tatham, R.L. \& Black, W.C. (1998). Multivariate data analysis. Englewood Cliffs, NJ: Prentice-Hall.

Heaphy, M.S., Gruska, G.F. (1995), The Malcolm Baldrige National Quality Award: A Yardstick for Quality Growth, Addison Wesley, Reading, MA. 
Joreskog, K. \& Sorbom D. 1989. LISREL 7: A guide to the Program and Applications. 2nd ed. Chicago: Statistical Package for the Social Sciences.

Ketchen, D. J. Jr., Rebarick, W., Hult, G. T. M., \& Meyer, D. (2008). Best value supply chains: A key competitive weapon for the 21st century. Horizons, 51, 235243

Kaplan, A. (2017). The conduct of inquiry: Methodology for behavioural science: Routledge.

Knotts, U.S., Parrish, L.G., Evans, C.R. (1993). What does the U.S. Business Community Really Think about the Baldrige Award? Quality Progress, May 1993.

Kotler, P. \& Armstrong, G. 1994, Principles of marketing. New Jersey. PrenticeHall.

Lee, H.L., Padmanabhan, P. and Whang, S. (1997a) Information distortion in a supply chaain: the bullwhip effect. Management Science, 43, 546-558.

Lee, H.L., Padmanabhan, P. and Whang, S. (1997b) Bullwhip effect in a supply chain. Sloan Management Review, 38, 93-102.

Lee, H.L., So, K.C., Tang C.S. (2000), - The Value of Information Sharing in a Two-Level Supply Chainl, Management Science, Vol 46 (5), pp. 626-643.

Lotfi, Z., Mukhtar, M., Sahran, S., \& Zadeh, A.T. (2013). Information Sharing in Supply Chain Management. 4th International Conference on Electrical Engineering and Informatics, Procedia Technology, 11, 298-304. DOI= 10.1016/j.protcy.2013.12.194

Mabert, Vincent A. 1992. Operations in the American economy: Liability or asset. Business Horizons. July-August. 35(4): 3-5. 
Malcom Baldrige (1992). National quality award application guidelines. Gaithersburg. USA: National Institute of Standards and Technology.

Mentzer, J. T., Dewitt, W.,\&Keebler, J. S. (2001). Defining supply chain management. Journal of Business Logistics

Mueller, Ralph O. 1996. Basic principles structural equation modelling: An introduction to LISREL and EQS. New York: Springer.

Nunnally, J. (1978). Psychometric Theory. New York: Mc Graw Hill Book Co

Rashed, C.A.A., Azeem, A., Halim, Z. (2010). Effect of Information and Knowledge Sharing on Supply Chain Performance: A Survey Based Approach. Journal of Operations and Supply Chain Management, 3 (2), 61-77.

Ramdas, K. and Spekman, R.E. (2000), -Chain or shackles: understanding what drives supply-chain performancell, Interfaces, Vol. 30 No. 4, pp. 3-21.

Richman, E. \& Zachary, W. (1993). Quality and reliability management: review and update. Quality Management, July/August.

Samson, D. \& Terziovski. (1999). The relationship between total quality management practices and operational performance. Journal of Operations Management. Vol.17(4), pg 393-409.

Saraph, Jayant V., Benson, George P., \& Schroeder, Roger G. (1989). An instrument for measuring the critical factors of quality management, Decision Sciences. Fall. 20, 810-829.

Schaffer, R H \& Thompson H. (1992). Successful change programs begin with results. Harvard Business Review. September/October, 80-89. 
Sterman, J.D. (1989) Modeling managerial behavior misperceptions of feedback in a dynamic decision making experiment. Management Science, 35, 321-339.

Stock, J. R., \& Boyer, S. L (2009). Developing a consensus definition of a supply chain management: A qualitative study. International Journal of Physical Distribution \& Logistics Management, 39(8), 690-711.

Suchman, E. A. (1967). Evaluative research: Principles and practice in public service and social action programs. New York: Russell Sage Foundation.

Tan KC, Kannan V, \& Handheld RB. (1998). Supply chain management: supplier performance and firm performance. International Journal of Purchasing and Materials Management. 34(3), 2-9.

Tillery, K.R. \& Rutledge, A.L. 1991. Quality-strategy and quality-management connections. International Journal of Quality \& Reliability Management (IJQ). 8(1): 71-77.

Utusan Malaysia (2008), Sekilas. Monday, 2 Jun 2008, page 1. www.utusan.com.my

Weiss, Carol H. (1998). Evaluation: Methods for Studying Programs and Policies. 2nd ed. Upper Saddle River, N.J.: Prentice-Hall.

Yu, Z., Yan, H., Cheng, T.C. (2001), -Benefit of information sharing with supply chain partnerships\|, Industrial Management and Data Systems, Vol 101 (3), pp. 114-119.

Zhou, H., Shou, Y., Zhai, X., Li, L., Wood, C., \& Wu, X. (2014) Supply chain practice and information quality: A supply chain strategy study, International Journal of Production Economics, 147, C, 624-633. 